\title{
On-Farm Management Decisions to Improve Beef Quality of Market Dairy Cows ${ }^{\star} \dagger$
}

\author{
C. A. Rogers, ${ }^{1}{ }^{\ddagger}$ A. C. Fitzgerald,,${ }^{1} \S$ M. A. Carr, ${ }^{2}$ B. R. Covey, ${ }^{1}$ \\ J. D. Thomas, ${ }^{1}$ and M. L. Looper ${ }^{1}, \|$ \\ ${ }^{1}$ Department of Animal and Range Sciences, \\ New Mexico State University, Las Cruces 88003 \\ ${ }^{2}$ Department of Agriculture, Angelo State University, \\ San Angelo, TX 76909
}

\begin{abstract}
A 3-phase study was conducted to assess on-farm management decisions to reduce antibiotic residue violations and improve carcass characteristics in market (cull) dairy cows. In Phase 1, questionnaires were mailed to dairy producers $(\mathrm{n}=142)$ to determine current on-farm management strategies for reducing antibiotic residues in market dairy cattle. In Phase 2, Holstein market cows $(n=77)$ were assigned randomly to each of the 3 feeding treatments $(0,30$, or $60 \mathrm{~d})$. Average daily gain (ADG), body condition score (BCS), and carcass characteristics were assessed. Phase 3 determined the meat withdrawal time of Holstein cows $(\mathrm{n}=62)$ administered procaine penicillin G. Eighty-six percent of dairy farms responding to the questionnaire had at least one cow condemned annually, and no producer had a designated feeding protocol for market cows prior to selling. In Phase 2, ADG was greater in cows fed for $30 \mathrm{~d}$ (1.4 $\pm 0.6 \mathrm{~kg} / \mathrm{d})$ than in cows fed for $60 \mathrm{~d}(0.9 \pm 0.4 \mathrm{~kg} / \mathrm{d})$. Additional feeding did not influence the carcass characteristics studied with the exception of kidney, pelvic and heart fat, which was higher in cows fed for $60 \mathrm{~d}$ compared with those fed for 0 and $30 \mathrm{~d}$. In Phase 3, $31 \%$ of cows treated with procaine penicillin $\mathrm{G}$ exceeded the 10-d label withdrawal recommendation by an average of $3.1 \pm 1.9 \mathrm{~d}$. Feeding market cows may not influ-
\end{abstract}

Received October 3, 2003

Accepted January 2, 2004.

Corresponding author: M. L. Looper; E-mail: mlooper@spa.ars. usda.gov.

*This paper was supported and approved for publication by the Director of the New Mexico Agricultural Experiment Station.

$\dagger$ Names are necessary to report factually on available data; however, the USDA does not guarantee or warrant the standard of the product, and the use of the name by the USDA implies no approval of the product to the exclusion of others that also may be suitable.

$\ddagger$ Current address: Colfax County Extension Office, Raton, NM 87740 .

§Current address: Department of Animal Sciences, University of Arizona, Tucson, AZ 85721.

|Current address: USDA-ARS, Dale Bumpers Small Farms Research Center, Booneville, AR 72927. ence carcass characteristics, but can increase ADG and may ensure that recommended meat withdrawal times for antibiotics are exceeded.

(Key words: dairy cow, carcass characteristic, antibiotic, additional feeding)

Abbreviation key: $\mathbf{A D G}=$ average daily gain, $\mathbf{B C S}=$ body condition score, $\mathbf{H C W}=$ hot carcass weight, LMA = longissimus muscle area, \%KPH = percentage kidney, pelvic, and heart fat.

\section{INTRODUCTION}

Food safety is an important issue for the agriculture industry. Use of antibiotics has significantly improved the health and production efficiency of food-producing animals; however, antimicrobial resistance is of concern. Antibiotic residues in meat consumed from foodproducing animals may potentially cause allergic reactions and alter the dynamics of microflora in the intestinal tracts of humans (Witte, 1998).

Approximately 33\% of beef production in the US is from market dairy cows (Smith et al., 1994b). Current replacement rates in the dairy industry average between 30 and $35 \%$ annually. Common reasons for culling dairy cows include lower milk prices, decreased milk production, and poor health (Bascom and Young, 1998; Lehenbauer and Oltjen, 1998). The National Animal Health Monitoring System's Dairy 2002 study showed a majority of cows were culled for udder health and reproductive problems (NAHMS, 2003).

With the implementation of Hazard Analysis Critical Control Point programs in meat processing plants (Stefan, 1997), the quality of incoming market cattle has and must continue to increase. Violations of residue regulations occur $>3$ times as often in carcasses from dairy cows $(1 \%)$ than from beef cows $(0.3 \%)$ when using a multi-residue bioassay (FSIS, 2000). Consequently, antibiotic residue violation in dairy cattle was the primary concern of industry representatives surveyed in the most recent National Market Cow and Bull Quality Audit (Roeber et al., 2001). 
Research has indicated additional feeding of market cows can increase body condition score (BCS), carcass value, carcass characteristics (Jones, 1983; Apple et al., 1999), and can potentially increase profits to the producer (Jones, 1983; Apple, 1999). Increased fat cover also decreased bruising associated with transport (Smith et al., 1994a). Additional feeding could decrease the possibility of antibiotic residue violations and increase carcass quality in market dairy cows. The objectives of this study were 1) to determine current on-farm management strategies for reducing antibiotic residues in market dairy cows, 2) to investigate the influence of additional feeding ( 30 or $60 \mathrm{~d}$ ) of market dairy cows on carcass characteristics, and 3) to determine clearance of antibiotics in meat tissues of unhealthy dairy cows.

\section{MATERIALS AND METHODS}

\section{Phase 1-Questionnaires}

Questionnaires (Figure 1) were mailed to 142 dairies (89\% of total dairies in New Mexico) to obtain information on management strategies of market dairy cattle. Questionnaires inquired as to the number of lactating cows on the farm, average annual replacement (culling) rates, marketing preferences of excess dairy cattle, methods of maintaining individual cow medication records, common drug administration methods, and reasons for culling (i.e., poor milk yield, reproductive failure, mastitis). Producers also were asked if a specific feeding protocol was utilized for market cows prior to sale.

\section{Phase 2-Additional Feeding Protocol}

Seventy-seven non-lactating Holstein market cows were obtained from 4 commercial dairies (>1500 cows per dairy) and assigned randomly to serve as controls (no additional feeding; $0 \mathrm{~d} ; \mathrm{n}=36$ ) or to each of 2 feeding treatments ( $30 \mathrm{~d} ; \mathrm{n}=21$ or $60 \mathrm{~d} ; \mathrm{n}=20$ ). Cows were fed at the New Mexico State University Campus Farm, Las Cruces.

Prior to the experimental feeding period, all cows were weighed and assigned a BCS of 1 to 5 , where $1=$ emaciation to $5=$ obese (Wildman et al., 1982). Cows were blocked by BCS with 2 to 3 cows per pen. Cows were administered an oral probiotic gel paste (30 g; RXV-BP-1 Bovine, AGRIpharm ${ }^{\circledR}$, Grapevine, TX) containing a bovine-specific mixture of bacteria. Furthermore, cows fed for 30 or $60 \mathrm{~d}$ received intramammary treatment with cephapirin sodium $\left(\right.$ ToDAY ${ }^{\circledR}$, Fort Dodge Animal Health, Fort Dodge, IA) to minimize udder infections during the feeding period.

Using commodities commonly found on large commercial dairies in the Southwest, a TMR was formu- lated consisting of $60 \%$ concentrate and $40 \%$ alfalfa hay (NRC, 1989; Table 1) and fed $2 \times$ daily. The grain mixture was purchased from a commercial feed company (HiPro Feeds, Roswell, NM), and the alfalfa was purchased locally. Bunks were visually evaluated prior to feeding, and the amount of feed was adjusted per pen intake with weighbacks (as-fed basis) recorded on a weekly basis. Ration samples were ground through a 2-mm screen in a Wiley mill before analyses for DM and CP. Percentage DM was calculated after drying for $24 \mathrm{~h}$, and percentage $\mathrm{CP}$ was calculated using the Kjeldahl procedure (AOAC, 1990).

Cows ( $\mathrm{n}=5$ groups; 3 to 10 cows per group) used as controls ( $0 \mathrm{~d}$; no additional feeding) were transported to Lonestar Packing (San Angelo, TX) from local dairies concurrently with cows after the designated feeding time (30 or $60 \mathrm{~d}$ ). Carcass data collected included hot carcass weight (HCW); longissimus muscle area (LMA); percentage kidney, pelvic, and heart fat (\%KPH); backfat; marbling; and fat coloring. Marbling scores were converted to a scale where $100=$ practically devoid, $200=$ traces, $300=$ slight, $400=$ small, $500=$ modest, $600=$ moderate, $700=$ slightly abundant, $800=$ moderately abundant, and $900=$ abundant. Yellow fat was scored on a 5-point scale, where $0=$ none to $4=$ severe.

\section{Phase 3-Antibiotic Withdrawal}

To determine antibiotic residue withdrawal time from meat tissues, unhealthy (predominately mastitis) lactating dairy cows $(\mathrm{n}=62)$ were administered procaine penicillin G ( $1 \mathrm{~mL} / 45 \mathrm{~kg}$ BW i.m.; Pfi-Pen G; Pfizer Animal Health, New York, NY;10-d meat withdrawal). Visual appraisal of each cow by the farm manager was utilized to estimate BW and medication dosage at label recommendation. To test for antibiotic residues, urine was collected and tested with a $\beta$-lactam-specific ELISA (Meatsafe $^{\mathrm{TM}}$ Residue Test; SilverLake Research, Monrovia, CA). A comparative urine and tissue test ( $\mathrm{n}=759$ samples) between inspection via the Food Safety and Inspection Service and the ELISA test indicated a sensitivity of $100 \%$ and a specificity of $94 \%$ for the Meatsafe ${ }^{\mathrm{TM}}$ residue test (Geisberg, 1999). Daily urine testing occurred from $2 \mathrm{~d}$ prior to label withdrawal time and continued until clearance of antibiotic residue was evident using the ELISA test.

\section{Statistical Analyses}

Results from Phase 1 questionnaires are reported as the percentage of producer responses to each question. Analyses of variance (SAS Inst., Inc., Cary, NC) were performed to determine the effect of feeding treatment 


\section{NMSU Cooperative Extension Service Questionnaire}

Strategies for reducing antibiotic residues in market dairy cattle

\section{Circle Your Position at the Dairy: Owner Manager Herdsman Other}

1. Number of lactating cows

2. Number of cows marketed (culled) per year

3. Give the percent of your cattle sold on a yearly basis for each of the following reasons:

*poor milk production
*mastitis $\%$
*reproductive problems
*locomotion (feet and leg) problems $\%$
*disease or other health problems $\%$
*other (please specify)

4. Where are your cattle sold (i.e. Lone Star, Caviness, etc.)?

5. Why do you choose this location(s)?

6. How are your cattle sold (i.e. on-the-rail, auction, etc.)?

7. What is the current price you are receiving for your cull animals (price/lb.)?

8. How many of your animals are condemned from the market over the period of a year?

9. Of your culled cattle that have been condemned, please give the reasons for condemnation (i.e. drug residue, cancer eye, downer cow, etc.).

10. If any of the above reasons for condemnation were for drug residue violation, what types of drugs were used (i.e. penicillin, oxytetracycline, gentamicin, etc.)?

11. What route of administration (intramuscular, subcutaneous, intravenous) is commonly used for each of the following:

vaccinations -

bST -

antibiotics -

12. What types of computer software, medication sheets, and(or) charts are utilized for keeping records on medicated cattle?

13. Do you feed any of your cull cattle on-farm prior to sale? If so, what is your feeding system (i.e. ration type, how much per day, etc.)?

14. Are there any other practices or procedures you follow concerning cull cows (i.e. watch market prices, sell in the spring, etc.)?

Thank you for participating in this NMSU marketing strategies questionnaire. It is our goal that your input will help dairy producers reduce the incidence of antibiotic residues in market dairy cows.

Figure 1. Example of questionnaire mailed to 142 dairies (89\% of total dairies in New Mexico) to obtain information on management strategies of market dairy cattle.

(independent variable) in Phase 2 on $\mathrm{BW}, \mathrm{BCS}, \mathrm{ADG}$, and carcass characteristics $(\mathrm{HCW}, \% / \mathrm{KPH}$, backfat thickness, LMA, marbling, and fat color). Treatment means were compared using the PDIFF statement of
SAS when protected by a significant $(P<0.05)$ treatment effect. Chi-square analysis, using the FREQ procedure of SAS, was used to determine the frequency of carcass condemnation. In Phase 3, cows exceeding the 
Table 1. Composition of total mixed ration of $60 \%$ concentrate and $40 \%$ forage fed to market cows for 30 or $60 \mathrm{~d}$.

\begin{tabular}{lc}
\hline Ingredient & $(\% \mathrm{DM})$ \\
\hline Corn, flaked & 40.1 \\
Soybean hulls & 11.7 \\
Soybean meal & 3.3 \\
Molasses & 2.3 \\
Mineral mix ${ }^{1}$ & 2.1 \\
Fat, animal & 1.1 \\
Alfalfa hay & 39.4 \\
DM & 93.3 \\
CP & 12.4 \\
Feed cost, ${ }^{2} \$$ /d per cow & 2.34 \\
\hline
\end{tabular}

${ }^{1}$ Formulated to meet or exceed mineral requirements (NRC, 1989).

${ }^{2}$ Calculated using actual cost of ingredients.

label withdrawal time and mean number of days exceeding the withdrawal time are reported as percentages.

\section{RESULTS AND DISCUSSION}

\section{Phase 1-Questionnaires}

Thirty-one percent (44 of 142) of dairy producers responded to questionnaires, representing 64,296 lactating cows, with an average herd size of 1461 cows. Average replacement rate (culling) was $33 \%$. Producers reported the following predominant reasons for cows leaving the herd: poor milk yield $(31 \%)$, reproductive failures (25\%), chronic mastitis (13\%), deteriorating locomotion $(9 \%)$, and disease or other health problems (8\%). Major reasons for culling cows from New York dairy farms were milk fever (47\%), mastitis (33\%), retained placenta (32\%), and ovarian cysts (21\%; Gröhn et al., 1998). Bascom and Young (1998) reported reasons for culling to be reproductive failure (20\%), mastitis (15\%), and low milk yield (14\%). The Dairy 2002 study (NAHMS, 2003) found a majority of cows were culled from the herd because of udder $(27 \%)$ and reproductive disorders $(26.5 \%)$.

Fifty percent of surveyed producers preferred to sell market cows to both auction barns and packing plants. Forty percent preferred to sell cows only to auctions, and $10 \%$ sold cows exclusively to the packer. Payne et al. (1999) reported $22 \%$ of California dairy producers sold cows directly to the processing facility. Decisions to liquidate market cows at either the auction or directly to the processing plants depended upon market prices and convenience (location relative to the dairy).

A majority (86\%) of dairy farms responding to the questionnaire had at least one cow carcass condemned annually. Of cows sent to packers, condemnation rates ranged from 0 to $20 \%$ with an average of $5 \%$ condemned annually per dairy. Reasons given for condemnation were predominantly cancer (34\%) and downer cows (26\%), with occurrences of pneumonia (7\%), peritonitis (5\%), and other diseases (7\%, e.g., mastitis, septicemia, Johnes, and edema). A survey of California producers reported $71 \%$ had a carcass condemned because of infection or illness during a 5-yr period (Payne et al., 1999).

According to responses from the questionnaire, a majority of vaccinations (74\%) were administered intramuscularly. Most vaccinations have dual administration routes (intramuscular or subcutaneous); however, producers surveyed utilized primarily intramuscular injection. The Dairy '96 study (NAHMS, 1996) revealed that $96 \%$ of dairy farms administered antibiotics to lactating and non-lactating cows with almost $44 \%$ of the injections administered intramuscularly. The most popular administration site was the upper hip and leg (NAHMS, 1996). Although injection site lesions in the round muscle have decreased during the last few years, $34.5 \%$ of dairy carcasses still had at least one injection site lesion compared with a $20 \%$ incident rate in beef cow carcasses (Smith et al., 1999; Roeber et al., 2000).

Fifty-seven percent of respondents utilized computerized medication records, 36\% utilized handwritten records, and $7 \%$ did not maintain any medical records. A survey of California dairy producers indicated $35 \%$ maintained computerized medical records, and $71 \%$ utilized paper records for individual cow treatment records (Payne et al., 1999). In that study, 2\% of producers surveyed kept no medical records. Kellogg et al. (2001) reported that almost $88 \%$ of dairy farms averaging $13,368 \mathrm{~kg}$ of milk per cow/yr owned a computer. The Dairy 2002 study (NAHMS, 2003) revealed that a majority $(74 \%)$ of producers utilized handwritten records, and $4.8 \%$ of producers surveyed did not maintain individual cow records.

No producer responding to our questionnaire had a specific feeding protocol for market cows prior to selling. Additional feeding of market cows can increase BCS, carcass value, and carcass characteristics (Jones, 1983; Apple et al., 1999) and can potentially increase profits to the producer (Jones, 1983; Apple, 1999). Additional feeding may decrease antibiotic residue violations and increase carcass quality in market dairy cows.

\section{Phase 2-Additional Feeding Protocol}

Feed intake did not differ among feeding treatments (17.7 \pm 1.4 and $17.3 \pm 3.5 \mathrm{~kg} / \mathrm{d}$ per cow for 30 - $\mathrm{d}$ and 60 $\mathrm{d}$ cows, respectively). Body condition scores were not different in 30-d fed cows compared with 60-d fed cows (Table 2). Schnell et al. (1997) reported a numerical increase in BCS of cows fed over $14 \mathrm{~d}$, but cows fed for only $14 \mathrm{~d}$ experienced a decrease in BCS. In the current study, ADG was greater $(P<0.05)$ in 30 -d fed cows than 
Table 2. Body condition score (BCS) and average daily gain (ADG) of market dairy cows fed 0,30 , or $60 \mathrm{~d}$.

\begin{tabular}{lllll}
\hline & \multicolumn{4}{c}{ Treatment } \\
\cline { 2 - 4 } Item & $0 \mathrm{~d}$ & $30 \mathrm{~d}$ & $60 \mathrm{~d}$ & $\mathrm{SE}^{1}$ \\
\hline Pre-feeding BCS & - & 2.2 & 2.6 & 0.5 \\
Post-feeding BCS & 2.6 & 2.8 & 3.2 & 0.6 \\
ADG, kg & - & $1.4^{\mathrm{x}}$ & $0.9^{\mathrm{y}}$ & 0.5 \\
\hline
\end{tabular}

${ }^{1}$ Pooled standard error.

${ }^{\mathrm{x}, \mathrm{y}}$ Means within a row with dissimilar superscripts $\operatorname{differ}(P<0.05)$.

in 60-d fed cows (Table 2). Matulis et al. (1987) reported ADG in beef cows increased between 29 and $56 \mathrm{~d}$ of feeding. The difference in ADG between treatments in our experiment may have been associated with increased gains during the first $30 \mathrm{~d}$ of feeding with lower gain efficiencies after the initial feeding period. Pritchard and Burg (1993) suggested that for beef cows to improve one USDA slaughter grade they would need to be fed an additional 60 to $100 \mathrm{~d}$.

Additional feeding did not influence carcass characteristics studied except \%KPH, which was different ( $P$ $<0.05$ ) among feeding groups (Table 3). Similarly, Apple et al. (1999) observed \% KPH to increase with increased BCS. Hot carcass weights, marbling scores, and LMA were not different among treatments. Schnell et al. (1997) found HCW, dressing percentage, and yield grades to increase with additional feeding up to $28 \mathrm{~d}$, but these remained constant from 28 to $42 \mathrm{~d}$ and from 42 to $56 \mathrm{~d}$ of additional feeding. Hot carcass weight, marbling, and LMA increased linearly with increased BCS in beef cows (Apple, 1999; Apple et al., 1999).

Backfat thickness and fat color did not differ among treatments (Table 3). Schnell et al. (1997) showed fat color to whiten (yellow to white) when beef and dairy cows were fed for $28 \mathrm{~d}$. Cranwell et al. (1996) found fat color to be whiter in beef cattle after $56 \mathrm{~d}$ of additional feeding. Differences in fat color between dairy and beef

Table 3. Hot carcass weight (HCW); longissimus muscle area (LMA); percentage kidney, heart, and pelvic fat (\% KPH); backfat thickness; and fat color of carcasses from market dairy cows fed 0,30 , or $60 \mathrm{~d}$.

\begin{tabular}{|c|c|c|c|c|}
\hline \multirow[b]{2}{*}{ Item } & \multicolumn{3}{|c|}{ Treatment } & \multirow[b]{2}{*}{$\mathrm{SE}^{1}$} \\
\hline & $0 \mathrm{~d}$ & $30 \mathrm{~d}$ & $60 \mathrm{~d}$ & \\
\hline $\mathrm{HCW}, \mathrm{kg}$ & 284 & 274 & 296 & 52 \\
\hline LMA, $\mathrm{cm}^{2}$ & 78.7 & 80.6 & 78.1 & 16.3 \\
\hline$\% \mathrm{KPH}$ & $1.6^{\mathrm{y}}$ & $1.0^{\mathrm{y}}$ & $2.1^{\mathrm{x}}$ & 0.4 \\
\hline Backfat thickness, cm & 0.13 & 0.10 & 0.13 & 0.13 \\
\hline Fat color ${ }^{2}$ & 0.52 & 0.19 & 0.39 & 0.7 \\
\hline
\end{tabular}

\footnotetext{
${ }^{1}$ Pooled standard error.

${ }^{2}$ Scale for visual appearance of yellow fat $(0=$ no yellow fat to $4=$ severe).

${ }^{\mathrm{x}, \mathrm{y}}$ Means within a row with dissimilar superscripts $\operatorname{differ}(P<0.05)$.
}

breeds were probably due to increased concentrates in lactating dairy rations compared with beef rations. Pasture-fed cattle have an abundance of yellow fat compared with cows maintained in a dry-lot environment.

Although not significant, additional feeding numerically decreased the incidence of carcass condemnation in the current study. Condemnation rates were 8.3, 10 , and $0 \%$ for 0,30 - and $60-\mathrm{d}$ fed cows, respectively. Condemnations resulted from various conditions (e.g., lymphoma, septicemia, and pyemia) and were not the result of antibiotic residues. The 1998 Food Safety and Inspection Service condemnation report indicated epithelioma, lymphosarcoma, septicemia, pyemia, and pneumonia as the top 5 reasons for condemning carcasses (FSIS, 1999). Seventy-one percent of California producers surveyed had a cow carcass condemned because of infection or illness during a 5-yr period (Payne et al., 1999).

The economic feasibility of feeding cull cows is dependent upon the time of year cattle are sold and feed costs. Mean price received from the sale of all market cows in the present study was $\$ 0.88 / \mathrm{kg}$ of live BW. Cows fed for $30 \mathrm{~d}$ gained an average of $1.4 \mathrm{~kg} / \mathrm{d}$. At the market prices received during this experiment, feeding market cows for $30 \mathrm{~d}$ would increase the value of the animal $\$ 1.23 / \mathrm{d}$. Feed costs per cow (Table 1 ) were $\$ 2.34$ resulting in a $\$ 1.11 /$ d loss. Feed for this study was purchased at a commercial feed mill in small allotments, therefore increasing overall input costs. Purchase of large quantities of feed commodities should reduce feed prices. Furthermore, cattle in the current study were sold during December when prices are usually lowest. Data collected from 1995 to 2003 by the National Agricultural Statistics Service (NASS, 2003) of the USDA report seasonal effects on the selling price of market beef and dairy cows. Prices generally are lowest during November and December, whereas highest prices received for market cows occur during March, April, and May. The primary reasons for reduced prices during fall months are attributed to the sale of culled beef cows after weaning calves. Our results confirm the importance of minimizing feed costs when feeding market cows. Because of the variability of market cows to gain weight, additional feeding of cows may not always be economically feasible when only performance is evaluated. However, feeding of antibiotic-treated cows may ensure recommended meat withdrawal times are exceeded and may reduce antibiotic residue violations.

\section{Phase 3-Antibiotic Withdrawal}

Thirty-one percent (19/62) of cows treated with procaine penicillin $\mathrm{G}$ exceeded the 10-d label withdrawal (clearance) recommendation by an average of $3.1 \pm 1.9$ 


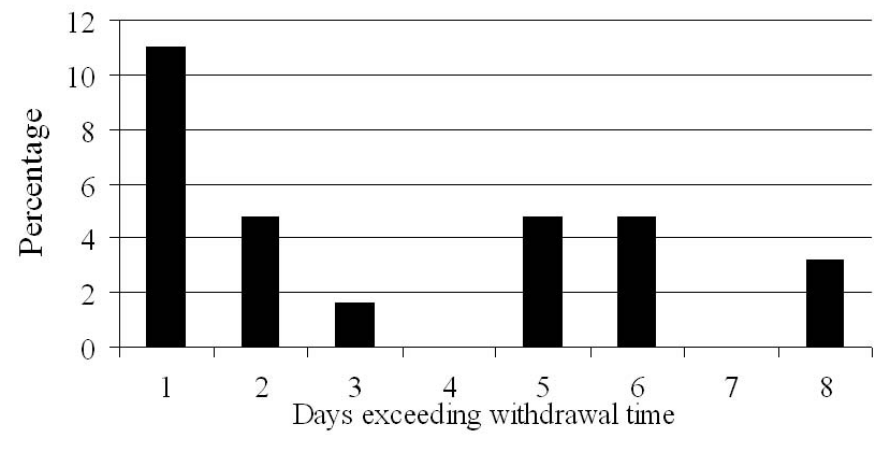

Figure 2. Percentage of cows $(n=62)$ exceeding 10 -d meat withdrawal time of procaine penicillin $\mathrm{G}$.

$\mathrm{d}$ (range, 1 to $8 \mathrm{~d}$; Figure 2). Occurrence of antibiotic residues is usually due to inadequate clearance time between administration and slaughter and extra label usage of health products. The majority of violations in a survey conducted by FSIS (2000) resulted from improper dosing and insufficient retaining of treated cows. It is common for unhealthy cows to have reduced feed and water intake. In addition, metabolism may be decreased in unhealthy cows and may partially explain why clearance exceeded the label withdrawal period in $31 \%$ of cows treated with procaine penicillin G. Furthermore, it is not common practice on a large, commercial dairy to weigh cows prior to administering medication, therefore increasing the possibility of over (or under) medicating cows and altering the expected withdrawal periods. Additional feeding of cows treated with procaine penicillin for $30 \mathrm{~d}$, as in Phase 2, would have ensured that the antibiotic withdrawal times were exceeded.

On-farm, urine-based antibiotic tests are available to ensure only antibiotic-free cows are sent to slaughter. Recently, Nebraska researchers have developed a microbial inhibition test that determines the presence of antibiotics in urine (IANR, 2003). Commercial antibiotic tests claiming $100 \%$ sensitivity and specificity were likely performed with a limited sample size or without appropriate representation (Gardner, 1997). Furthermore, many evaluations performed in a laboratory setting typically overestimate the sensitivity and specificity of a test as compared with a more realistic field test. A test's qualitative outcome (positive or negative) will depend on the level of substance being tested (Gardner, 1997). With microbial inhibitor tests, false-positives tend to be a common problem, whereas false-negatives are dependent on the sensitivity of the test organism to the antibiotic (Griffin, 2001).

Dairy producers need to implement on-farm residual testing programs (meat and milk) to avoid introducing food-borne residues to consumers. However, dairy producers are unlikely to implement Hazard Analysis Critical Control Point testing programs voluntarily. Approximately $10 \%$ of the dairy producers in the US have volunteered to implement a 10-point Milk and Dairy Beef Quality Assurance Program to prevent antibiotic residues (Gardner, 1997). Many of the antibiotic residue concerns involving the dairy industry could be decreased with proper medical record documentation, increased education, and the adaptation of national standards for milk and dairy beef (Cullor, 1997).

\section{CONCLUSIONS}

Most dairy farms surveyed had at least one cow condemned annually, and no farm utilized a specific market-cull cow feeding protocol. Feeding market cows may not influence carcass characteristics, but can increase ADG. Furthermore, antibiotic-treated market cows may exceed recommended withdrawal times for meat and cause antibiotic residue violations at processing. Health and the ability to gain weight are extremely variable in market cows. Therefore, not all market cows are suitable candidates for additional feeding protocols; non-lactating cows are less efficient than lactating cows. Dairy producers should evaluate individual market cows and consider management strategies, such as additional feeding, when cost of feed is economically feasible, to decrease the incidence of carcass condemnation and antibiotic residues in meat tissues.

\section{ACKNOWLEDGMENTS}

The study was supported, in part, by the National Cattlemen's Beef Association on behalf of the Cattlemen's Beef Board through its $\$ 1$ per head check-off program. The authors gratefully acknowledge the dairy producers of New Mexico for responding to our questionnaire and supplying cattle for these studies. Appreciation is expressed to $\mathrm{P}$. Kloppenburg, Nutri-Tech Consulting Inc., for ration formulation.

\section{REFERENCES}

AOAC. 1990. Official Methods of Analysis. 15th ed. Association of Official Analytical Chemists, Arlington, VA.

Apple, J. K. 1999. Influence of body condition score on live and carcass value of cull beef cows. J. Anim. Sci. 77:2610-2620.

Apple, J. K., J. C. Davis, J. Stephenson, J. E. Hankins, J. R. Davis, and S. L. Beaty. 1999. Influence of body condition score on carcass characteristics and subprimal yield from cull beef cows. J. Anim. Sci. 77:2660-2669.

Bascom, S. S., and A. J. Young. 1998. A summary of the reasons why farmers cull cows. J. Dairy Sci. 81:2299-2305.

Cranwell, C. D., J. A. Unruh, J. R. Brethour, and D. D. Simms. 1996. Influence of steroid implants and concentrate feeding on carcass and longissimus muscle sensory and collagen characteristics of cull beef cows. J. Anim. Sci. 74:1777-1783. 
Cullor, J. S. 1997. HACCP (Hazard Analysis of Critical Control Points): Is it coming to the dairy? J. Dairy Sci. 80:3449-3452.

FSIS. 1999. Animal disposition reporting system (ADRS), fiscal year (FY) 1998 slaughter and condemnation data. Food Safety and Inspection Service - United States Department of Agriculture. [Online]. Available: http://www.fsis.usda.gov/OPHS/adrsdata/ 1998adrs/adrsfy98.htm. Accessed September 3, 2002.

FSIS. 2000. National residue data, "The Red Book". Food Safety and Inspection Service - United States Department of Agriculture. [Online]. Available: http://www.fsis.usda.gov/ OPHS/red2000/. Accessed July 31, 2002.

Gardner, I. A. 1997. Testing to fulfill HACCP (Hazard Analysis of Critical Control Points) requirements: Principles and examples. J. Dairy Sci. 80:3453-3457.

Geisberg, M. 1999. Meatsafe $\beta$-lactam antibiotic residue test: A new tool for residue management. Pages 518-519 in Am. Vet. Med. Assoc. Conf. Proc., AVMA, Schaumburg, IL.

Griffin, D. 2001. Pre-harvest antibiotic screening test (PHAST). Univ. Nebraska Great Plains Educ. Ctr., Lincoln. [Online]. Available: http://www.gpvec.unl.edu/files/feedlot/CVC-KC2002/ AbScreening-PHAST.doc. Accessed December 3, 2003.

Gröhn, Y. T., S. W. Eicker, V. Ducrocq, and J. A. Hertl. 1998. Effect of diseases on the culling of Holstein dairy cows in New York State. J. Dairy Sci. 81:966-978.

IANR. 2003. Antibiotic test is another tool for food safety assurance. Institute of Agriculture and Natural Resources - Univ. Nebraska, Lincoln. [Online]. Available: http://ianrnews.unl.edu/static/ 0305025.shtml. Accessed December 2, 2003.

Jones, S. D. M. 1983. Tissue growth in young and mature cull Holstein cows fed a high energy diet. J. Anim. Sci. 56:64-70.

Kellogg, D. W., J. A. Pennington, Z. B. Johnson, and R. Panivivat. 2001. Survey of management practices used for the highest producing DHI herds in the United States. J. Dairy Sci. 84(E. Suppl.):E120-E127. [Online]. Available: http://www.adsa.org/jds/ papers/2001/jds_es120.pdf.

Lehenbauer, T. W., and J. W. Oltjen. 1998. Dairy cow culling strategies: Marketing economic culling decisions. J. Dairy Sci. 91:264-271.

Matulis, R. J., F. K. McKeith, D. B. Faulkner, L. L. Berger, and P. George. 1987. Growth and carcass characteristics of cull cows after different times-on-feed. J. Anim. Sci. 65:669-674.

NAHMS. 1996. Part III. Reference of 1996 dairy health and health management. National Animal Health Monitoring System. \#N212.1196. USDA:APHIS:VS, Ft. Collins, CO. [Online]. Available: http://www.aphis.usda.gov/vs/ceah/cahm/Dairy_Cattle/ dry3-96.pdf. Accessed November 10, 2002.

NAHMS. 2003. Part II: Changes in the United States dairy industry, 1991-2002. National Animal Health Monitoring System. \#N388.0603. USDA:APHIS:VS, CEAH, Ft. Collins, CO. [Online]. Available: http://www.aphis.usda.gov/vs/ceah/cahm/Dairy Cattle/Dairy02/dairy2002-ptII.pdf. Accessed November 10, 2002.
NASS. 2003. Cattle prices received, 1995-2003. National Agricultural Statistics Service-United States Department of Agriculture. [Online]. Accessed: http://www.usda.gov/nass/aggraphs/ priceca.htm. Accessed October 18, 2002.

National Research Council. 1989. Pages 89-110 in Nutrient Requirements of Dairy Cattle. 6th rev. ed. Natl. Acad. Sci., Washington, DC.

Payne, M., C. M. Bruhn, B. Reed, A. Scearce, and J. O’Donnell. 1999. On-farm quality assurance programs: A survey of producer and industry leader opinions. J. Dairy Sci. 82:2224-2230.

Pritchard, R. H., and P. T. Burg. 1993. Feedlot performance and carcass traits of cull cows fed for slaughter. South Dakota State Univ., Beef Report. Cattle 93-20:101.

Roeber, D. L., G. C. Smith, J. A. Scanga, R. C. Cannell, E. R. Behrends, K. E. Belk, J. D. Tatum, and J. N. Sofos. 2000. Beef quality assurance audits: Incidence of injection-site damage in top sirloin butts and in muscles of the round-October 1999 through September 2000. Final Report to the National Cattlemen's Beef Association. Colorado State Univ., Ft. Collins, CO.

Roeber, D. L., P. D. Miles, C. D. Smith, K. E. Belk, T. G. Field, J. D. Tatum, J. A. Scanga, and G. C. Smith. 2001. National market cow and bull beef quality audit-1999: A survey of producer-related defects in market cows and bulls. J. Anim. Sci. 79:658-665.

Schnell, T. D. K. E. Belk, J. D. Tatum, R. K. Miller, and G. C. Smith. 1997. Performance, carcass and palatability traits for cull cows fed high-energy concentrate diets for $0,14,28,42$, or 56 days. J. Anim. Sci. 75:1195-1202.

Smith, G. C., J. B. Morgan, J. D. Tatum, C. C. Kukay, M. T. Smith T. D. Schnell, and G. G. Hilton. 1994a. Improving the consistency and competitiveness of non-fed beef; and, improving the salvage value of cull cow and bulls. Final Report of the National NonFed Beef Quality Audit. National Cattlemen's Beef Association, Englewood, CO.

Smith, G. C., J. B. Morgan, J. D. Tatum, C. C. Kukay, M. T. Smith, T. D. Schnell, and G. G. Hilton. 1994b. Opportunities for enhancing value and improving the quality of beef. Pages 1-10 in The Executive Summary of the National Non-Fed Beef Quality Audit - Special Section: Dairy Cattle. Colorado State Univ., Ft. Collins, CO.

Smith, G. C., R. C. Cannell, K. E. Belk, J. D. Tatum, J. N. Sofos, and G. R. Schmidt. 1999. Beef quality assurance audits: Incidence of injection-site damage in top sirloin butts and in muscles of the round-March through September 1999. Final Report to the National Cattlemen's Beef Association. Colorado State Univ., Ft. Collins, CO.

Stefan, G. 1997. Food safety issues affecting the dairy beef industry. J. Dairy Sci. 80:3458-3462.

Wildman, E. E., G. M. Jones, P. E. Wagner, and R. L. Boman. 1982. A dairy cow body condition scoring system and its relationship to selected production characteristics. J. Dairy Sci. 65:495-501.

Witte, W. 1998. Medical consequences of antibiotic use in agriculture. Science 279:996-997. 